\title{
THE ROLE OF SOME XENOBIOTIC BIOTRANSFORMATION GENES SNP IN THE DEVELOPMENT OF ACUTE PANCREATITIS
}

Samgina TA $\bowtie$, Nazarenko PM, Polonikov AV, Lazarenko VA

Kursk State Medical University, Kursk, Russia

Genetically determined features of the xenobiotic biotransformation system play an important role in the development of acute pancreatitis (AP) and its complications. The aim of this study was to assess the contribution of 3 SNPs (CYP1A1 -462 T>C rs1048943, CYP2E1 -1293 G>C rs3813867 and ABCB1 -3435 G>A rs 1045642) to the development of AP and its complications. DNA samples were collected from 547 unrelated patients with AP (154 women and 393 men; mean age $48.9 \pm 13.1$ years) undergoing therapy at surgery departments of Kursk and 573 unrelated individuals without gastrointestinal diseases (161 women and 412 men; mean age $47.8 \pm 12.1$ years). The polymorphisms were genotyped by PCR using TagMan probes for allele discrimination. Infected pancreatic necrosis (IPN) was observed in 97 patients; 101 patients developed a pseudocyst (PC); 111 patients had a peripancreatic necrosis (PN). AP was the most common in the carriers of the A allele in $A B C B 1 \mathrm{G}>\mathrm{A}$ ( $\mathrm{rs}$ 1045642) $(p=0.0008)$. The carriers of the $\mathrm{G} / \mathrm{G}$ genotype rarely developed both $\mathrm{AP}\left(p=5 \cdot 10^{-4}\right)$ and its complications: IPN $\left(p=0.03^{\mathrm{P}}\right)$, PN $\left(p=0.036^{\mathrm{P}}\right)$, PC $\left(p=0.04^{\mathrm{P}}\right)$. The carriers of the $\mathrm{G} / \mathrm{C}-\mathrm{C} / \mathrm{C}$ CYP2E1 G>C (rs3813867) genotypes who had no long-term history of alcohol abuse rarely developed AP $(p=0.03)$. The carriers of the G/C CYP2E1 (rs3813867) genotype tended to develop pseudocysts $\left(p=0.05 \mathrm{O}^{\mathrm{D}}\right)$. AP was more frequently complicated by IPN $\left(p=0.009^{\mathrm{P}}\right), \mathrm{PN}\left(p=0.003^{\mathrm{P}}\right)$ and PC $\left(p=0.003^{\mathrm{D}}\right)$ in the carriers of the C/C CYP1A1 T>C (rs1048943) genotype. A milder course of AP was typical for the carriers of the G/G ABCB1 G>A (rs1045642) genotype; a more severe course was characteristic of the carriers of the C/C CYP1A1 T>C (rs1048943) genotype.

Keywords: acute pancreatitis, xenobiotic biotransformation enzyme genes, genetic polymorphism, rs1045642, rs1048943, rs3813867

Author contribution: Samgina TA conceived and designed the study, conducted clinical and molecular-genetic tests, analyzed and interpreted the obtained data, and wrote the manuscript; Nazarenko PM supervised surgical treatment and postoperative care at Kursk City Clinical Hospital № 4 and recruited patients for the study; Polonikov AV supervised genetic testing; Lazarenko VA supervised the study.

Compliance with ethical standards: the study was approved by the Ethics Committee of Kursk State Medical University (Protocol № 3 dated March 11, 2013). The patients gave informed consent to participate.

$\triangle$ Correspondence should be addressed: Tatiana A. Samgina

K. Marksa, 3, 305000; Kursk, tass@list.ru

Received: 05.01.2020 Accepted: 08.02.2020 Published online: 15.02.2020

DOI: $10.24075 /$ brsmu.2020.008

\section{ЗНАЧЕНИЕ ОДНОНУКЛЕОТИДНОГО ПОЛИМОРФИЗМА НЕКОТОРЫХ ГЕНОВ СИСТЕМЫ БИОТРАНСФОРМАЦИИ КСЕНОБИОТИКОВ В РАЗВИТИИ ОСТРОГО ПАНКРЕАТИТА}

Т. А. Самгина $\bowtie$, П. М. Назаренко, А. В. Полоников, В. А. Лазаренко

Курский государственный медицинский университет, Курск, Россия

Генетически детерминированные особенности функционирования системы биотрансформации ксенобиотиков играют важную роль в развитии острого панкреатита (ОП) и его осложнений. Целью работы было определить вклад однонуклеотидных полиморфизмов генов CYP1A1 -462 Т>C rs1048943, CYP2E1 -1293 G>C rs3813867 и ABCB1 -3435 G>A rs1045642 в развитие ОП и его осложнений. Образцы ДНК получали от 547 неродственных больных ОП (154 женщины и 393 мужчины; средний возраст составил 48,9 \pm 13,1), находившихся на стационарном лечении в хирургических отделениях города Курска и 573 неродственных индивида без заболеваний ЖКТ (161 женщина и 412 мужчин; средний возраст - 47,8 \pm 12,1). Генотипирование полиморфизма изучаемых генов выполняли методом ПЦР путем дискриминации аллелей с помощью ТаqМап-зондов. У 97 пациентов развился инфицированный панкреонекроз (ИП), у 101 - псевдокиста (ПК), у 111 — гнойно-некротический перипанкреатит (ГНП). Установлено, что у носителей аллеля А гена $A B C B 1 \mathrm{G}>\mathrm{A}(\mathrm{rs} 1045642)$ чаще развивался ОП ( $p=0,0008)$, у носителей генотипа $\mathrm{G} / \mathrm{G}$ редко развивался как ОП ( $\left.p=5 \cdot 10^{-4}\right)$, так и его осложнения: ИП ( $\left.p=0,03^{\mathrm{P}}\right)$, ГНП ( $\left.p=0,036^{\mathrm{P}}\right)$, ПК ( $\left(p=0,04^{\mathrm{P}}\right)$. Отсутствие длительного злоупотребления алкогольными напитками у носителей генотипов G/C-C/C CYP2E1 G>C (rs3813867) редко приводило к развитию ОП ( $p=0,03)$, у носителей генотипа G/C CYP2E1 (rs3813867) (p = 0,05OD) чаще возникала псевдокиста. У носителей генотипа C/C CYP1A1 T>C (rs1048943) ОП чаще осложнялся ИП (p = 0,009R), ГНП ( $\left.p=0,003^{R}\right)$, ПК $\left(p=0,003^{D}\right)$. В целом, для носителей генотипов G/G ABCB1 G>A (rs1045642) было характерно более легкое течение ОП, тяжелое течение было характерно для носителей C/C CYP1A1 T>C (rs1048943).

Ключевые слова: острый панкреатит, гены ферментов биотрансформации ксенобиотиков, генетический полиморфизм, rs1045642, rs1048943, rs3813867

Информация о вкладе авторов: Т. А. Самгина - написание статьи, разработка концепции и дизайна, анализ и интерпретация данных, реализация клинических и молекулярно-генетических методов исследования, статистическая обработка данных; П. М. Назаренко - руководство хирургической частью исследования, лечение и подбор больных в ОБУЗ КГКБ № 4; А. В. Полоников - руководство генетической частью исследования; В. А. Лазаренко - руководство исследованием

Соблюдение этических стандартов: исследование одобрено этическим комитетом Курского государственного университета (протокол № 3 от 11 марта 2013 г.). Все участники исследования подписали добровольное информированное согласие.

$\triangle$ Для корреспонденции: Татьяна Александровна Самгина ул. К. Маркса, д. 3, 305000; г. Курск; tass@list.ru

Статья получена: 05.01.2020 Статья принята к печати: 08.02.2020 Опубликована онлайн: 15.02.2020

DOI: $10.24075 /$ vrgmu.2020.008

In recent years, there has been a lot of research into the contribution of environmental chemicals and disrupted prooxidant-antioxidant balance to the development of acute pancreatitis (AP). For example, acute nonbiliary pancreatitis has been associated with smoking [1]; smokers and alcohol abusers with AP have been shown to be at increased risk for necrotizing pancreatitis [2]. Despite numerous research efforts, though, genetic mechanisms underlying predisposition 
to $\mathrm{AP}$ and its complications remain understudied. Still, it is obvious that an important role here is played by the genetically determined features of xenobiotic biotransformation and antioxidant defense systems.

The transmembrane protein $\mathrm{ABCB} 1$ is a member of the subfamily of broad-specificity ATP-dependent drug/xenobiotic transporters. This protein inhibits accumulation of narcotic drugs in multidrug resistant cells and often mediates resistance to antitumor medications. ABC genes constitute 7 different subfamilies. The ABCB1 protein is a member of the MDR/TAP subfamily; the gene encoding this protein is located on the chromosomal region $7 \mathrm{q} 21.12$. $A B C B 1$ is primarily expressed in the testicles, muscles, stomach and pancreas. There have been studies of its role in the development of colorectal cancer [3, 4] but no statistically significant associations have been reported. The role of this gene in AP has never been investigated.

So far, the cytochrome P450 oxidase system remains the most well-studied. It comprises CYP1, CYP2 and CYP3 enzyme families responsible for the metabolism of foreign compounds in mammals.

It is reported that polymorphisms of the P450, CYP1A1 and CYP2E1 genes are associated with increased activity of enzymes in patients with pancreatitis [5]. The researchers conclude that CYP1A1 is the most implicated in pancreatitis; it triggers the proteinase cascade, promoting DNA replication and tissue proliferation, generates oxygen radicals, forms reactive intermediates during xenobiotic metabolism, and can activate various carcinogens.

It is known that CYP1A1 (aromatic ligand-dependent aryl hydrocarbon hydroxylase) converts polycyclic aromatic hydrocarbons into highly active mutagenic metabolites in the first phase of xenobiotic biotransformation. The gene encoding the key enzyme involved in this process is located on the chromosomal region 15q24.1. Today, 19 gene polymorphisms are known that play a role in the development of cancer and occupational diseases [6].

CYP2E1 (cytochrome P450 2E1) encodes cytochrome P450 proteins (monooxygenases) that catalyze many reactions related to the metabolism of medicinal drugs and the production of cholesterol, steroids and other lipids. This protein is found in the endoplasmic reticulum and can be activated by ethanol, diabetes and fasting. The enzyme participates in the metabolism of ethanol, acetone, ethylene glycol, and tobacco smoke premutagens [7]. The gene itself is located on 10q26.3 and expressed primarily in adipose tissue, esophageal mucosa and peripheral blood.

Comparison of allelic and genotype frequencies of $A D H 2$, ADH3, ALDH2, CYP2E1, IL1, IL6, IL8, and TNF has revealed that CYP2E1 and ALDH2 are significantly less frequent in patients with chronic pancreatitis than in healthy controls [8]. At the same time, no association has been detected between the CYP2E1 polymorphism and alcohol-induced pancreatitis in a studied Asian population [9, 10]. It is reported that carriers of the m2/m2 CYP1A1 genotype might be more predisposed to alcoholic cirrhosis and alcohol-related pancreatitis [11]. An association has been established between the polymorphism P450 CYP1A1 lle105Val and the increased risk of chronic pancreatitis [12]. The $A \rightarrow G$ transition results in a leucine-to-valine substitution in codon 462 of the cytochrome molecule (lle462Val); consequently, the activity of the produced enzyme increases twofold in comparison with the "original" protein, which can increase the concentrations of underoxidized toxic intermediates and lead to the accumulation of free radicals [13-15].

Thus, polymorphic variants of genes coding for the enzymes of xenobiotic biotransformation may be implicated in AP. The aim of this study was to investigate a possible association between AP/its complications and the following SNPS: CYP1A1-462 T>C rs1048943, CYP2E1-1293 G>C rs3813867 and $A B C B-3435$ G>A rs1045642.

\section{METHODS}

DNA samples were collected from 547 unrelated inpatients with AP (154 women and 393 men) undergoing therapy at surgery departments of Kursk in 2012-2015 and 573 unrelated individuals without gastrointestinal diseases (161 women and 412 men). The mean age of the patients was $48.9 \pm 13.1$ years, the mean age of the healthy controls, $47.8 \pm 12.1$ years. The following inclusion criteria were applied: 1) the established diagnosis of AP; 2) age of 18-80 years; 3) the absence of biliary pathology, such as gallstones, pancreas divisum and pancreatic injury, including injuries due to surgery/endoscopic manipulations; 4) no previous history of pancreotoxic drugs (hypothiazid, NSAIDs, steroid anti-inflammatory drugs), the absence of autoimmune disorders, infections, allergies (to paints and varnishes), pregnancy/menopause-related endocrine pathology, diseases of neighboring gastrointestinal organs; 5) no family history of AP. Patients who did not meet the inclusion criteria were excluded from the study.

AP was diagnosed using the AP classification developed by the Russian Society of Surgeons in 2014, which is based on the Atlanta-92 classification and its modifications proposed by the International Association of Pancreatology in collaboration with the International Acute Pancreatitis Classification Working Group in Cochin in 2011 [16,17]; the patients underwent a standard examination, as well as laboratory (complete blood count and biochemistry) and instrumental (US and MRI of the pancreas, EGD) tests.

The patients were also asked about their lifestyle, including addictions such as smoking and alcohol abuse regarded as the major risk factors for AP $[18,19]$.

The participants were distributed into two groups depending on the amount of weekly consumed alcohol: 1) consumption below $200 \mathrm{~g}$ ethanol a week; 2) consumption above $200 \mathrm{~g}$ ethanol a week. This threshold is the median value (grams of pure ethanol) of the maximum weekly alcohol intake considered safe in many countries [20]. Another two groups were formed based on the frequency of alcohol consumption: 1) 1 or 2 days a month or less often; 2) 1 day a week or more often. Also, the participants were divided into two groups based on the total duration of alcohol consumption: 1) less than 10 years; 2) 10 years or more.

Samples of the patients' whole venous blood (5-10 ml) were collected into plastic EDTA-containing $(0.5 \mathrm{M})$ test tubes. Then, the samples were frozen and stored at $-20{ }^{\circ} \mathrm{C}$ until further DNA isolation. DNA was isolated using a standard twostep phenol-chloroform extraction and precipitation in ethanol. First, white blood cells were lysed. Briefly, the white blood cell pellet obtained by centrifuging the sample twice with a sodium phosphate buffer $(\mathrm{pH}=7.8)$ was lysed in the solution containing a TE-buffer, proteinase $\mathrm{K}$ and $0.4 \%$ sodium dodecyl sulfate (SDS) for $12 \mathrm{~h}$ at $42{ }^{\circ} \mathrm{C}$. Then, genomic DNA was isolated from the obtained cell lysate. The first step was extraction in phenol and $10 \mathrm{mM}$ Tris- $\mathrm{HCl}(\mathrm{pH}=8.0)$, the second, in phenol and chloroform (1:1); in the final step, extraction was performed in chloroform only. Genomic DNA was precipitated in ice-cold 96\% ethanol, air-dried and dissolved in the TE-buffer. Then, the DNA concentration was measured. The obtained DNA was frozen at $-20^{\circ} \mathrm{C}$ until genotyping.

Genotyping of CYP1A1 -462 T>C rs1048943, CYP2E1 -1293 G>C rs3813867 and ABCB1 -3435 G>A rs1045642 
was performed using real-time PCR. Alleles were discriminated using TaqMan probes, a CFX96 PCR detection system (Bio-Rad Laboratories; USA) and commercial TaqMan SNP Genotyping Assays (Applied Biosystems; USA). Repeated genotyping of randomly (blindly) selected samples (10\% of the total sample size) demonstrated $100 \%$ repeatability of the results. Categorical variables were compared using Pearson's $\chi^{2}$. Normally distributed quantitative variables were compared using Student's T-test; Mann-Whitney $U$ test was applied to compare the variables with non-normal distribution. Conformity genotype frequencies to Hardy-Weinberg expectations was tested using Pearson's $\chi^{2}$. Associations of alleles and genotypes with the risk of pancreatitis were measured using the odds ratio (OR). Statistical analysis was carried out in Statistica 6.0 (StatSoft; USA).

\section{RESULTS}

No associations were established between the risk of AP and the two following polymorphisms: CYP1A1 T>C and CYP2E1 G $>C$ (Table 1).

The carriers of the A allele in $A B C B 1 \mathrm{G}>\mathrm{A}$ (rs1045642) were at increased risk for AP, unlike the carriers of the G/G genotype, who were at low risk for this condition.

AP was rarely observed in the carriers of the $\mathrm{G} / \mathrm{C}-\mathrm{C} / \mathrm{C}$ CYP2E1 G>C (rs3813867) genotypes who did not have a long history of alcohol abuse (Table 2).

Infected pancreatic necrosis occurred more frequently in the carriers of the C/C CYP1A1 T>C (rs1048943) genotype than in the carriers of the $\mathrm{G} / \mathrm{G} A B C B 1 \mathrm{G}>\mathrm{A}$ ( $\mathrm{rs} 1045642)$ genotype (Table 3).

Pancreatic pseudocysts were observed in the carriers of the C/C CYP1A1 T>C (rs1048943) and G/C CYP2E1 (rs3813867) genotypes more often than in the carriers of the $\mathrm{G} / \mathrm{G} A B C B 1$ G>A rs1045642 genotype (Table 4).
Peripancreatic necrosis was the most common complication of $\mathrm{AP}$ in the carriers of the C/C CYP1A1 T>C (rs1048943) genotype; it rarely occurred in the carriers of the $\mathrm{G} / \mathrm{G} A B C B 1$ G>A (rs1045642) genotype (Table 5).

\section{DISCUSSION}

Biotransformation is the enzyme-driven metabolic conversion of foreign compounds (xenobiotics) that can be broken down into 3 stages: activation, detoxication and clearance $[21,22]$. A lot of enzymes participate in this process. The role of genes involved in xenobiotic biotransformation (CYP2E1 and CYP1A1) in promoting alcohol-induced pancreatitis and liver cirrhosis has been studied in Brazilian alcohol abusers; no association has been detected between these genes and pancreatitis [11].

It is known that cytochromes P450 are involved in the bioactivation of polycyclic aromatic hydrocarbons. CYP1A1 is not found in healthy tissue; its expression is only induced by xenobiotics. The association between the C/C CYP1A1 T>C (rs1048943) genotype and the increased risk of AP established in this study suggests a change in the activity of the encoded enzyme and a rise in the concentration of underoxidized toxic metabolites that exert an aggressive effect on pancreatic tissue.

The role of CYP2E1 polymorphisms in the development of acute pancreatitis has not been studied before, but there are reports suggesting that the minor allele of this gene might be protective against methanol poisoning [23]. In our study, AP was more often observed in the carriers of the G/C CYP2E1 (rs3813867) genotype, but if the total duration of alcohol abuse was less than 10 years, the carriers of the $\mathrm{G} / \mathrm{C}-\mathrm{C} / \mathrm{C}$ CYP2E1 $\mathrm{G}>\mathrm{C}$ (rs3813867) genotypes were more resistant to the harmful effects of alcohol and rarely developed AP.

The ABCB1 gene codes for P-glycoprotein; it is an efflux transporter that participates in the clearance of xenobiotics, preventing their accumulation in a person's organs and tissues

Table 1. The analysis of the associations between the risk of AP and the alleles/genotypes of the polymorphic genes encoding the enzymes involved in xenobiotic biotransformation and antioxidant defense (the codominant model)

\begin{tabular}{|c|c|c|c|c|c|}
\hline \multirow{2}{*}{$\begin{array}{c}\text { Gene } \\
\text { (SNP ID) }\end{array}$} & \multirow[b]{2}{*}{ Genotype, allele } & \multicolumn{2}{|c|}{$n(\%)$} & \multirow[b]{2}{*}{$p$} & \multirow[b]{2}{*}{ cor $\mathrm{OR}(95 \% \mathrm{Cl})$} \\
\hline & & $\begin{array}{l}\text { Healthy individuals } \\
\qquad(n=573)\end{array}$ & Patients $(n=547)$ & & \\
\hline \multirow{4}{*}{$\begin{array}{l}\text { CYP1A1 -462 T>C } \\
\text { (rs1048943) }\end{array}$} & $T / T$ & $507(91.0)$ & 489 (90.2) & \multirow{3}{*}{0.07} & 1.00 \\
\hline & $\mathrm{T} / \mathrm{C}$ & $49(8.8)$ & $46(8.5)$ & & $0.97(0.64-1.48)$ \\
\hline & $\mathrm{C} / \mathrm{C}$ & $1(0.2)$ & $7(1.3)$ & & $7.26(0.89-59.21)$ \\
\hline & $\mathrm{C}$ & 0.05 & 0.06 & 0.3 & $1.22(0.83-1.79)$ \\
\hline \multirow{4}{*}{$\begin{array}{l}\text { CYP2E1 -1293 G>C } \\
\text { (rs3813867) }\end{array}$} & $\mathrm{G} / \mathrm{G}$ & $532(95.0)$ & $513(94.0)$ & \multirow{3}{*}{0.46} & 1.00 \\
\hline & $\mathrm{G} / \mathrm{C}$ & $22(3.9)$ & $29(5.3)$ & & $1.37(0.78-2.41)$ \\
\hline & $\mathrm{C} / \mathrm{C}$ & $6(1.1)$ & $4(0.7)$ & & $0.69(0.19-2.46)$ \\
\hline & $\mathrm{C}$ & 0.03 & 0.034 & 0.64 & $1.12(0.70-1.80)$ \\
\hline \multirow{4}{*}{$\begin{array}{l}A B C B 1-3435 \mathrm{G}>\mathrm{A} \\
(\mathrm{rs} 1045642)\end{array}$} & $\mathrm{A} / \mathrm{A}$ & $158(28.3)$ & $183(33.5)$ & \multirow{3}{*}{$5 \cdot 10^{-4}$} & 1.00 \\
\hline & $\mathrm{G} / \mathrm{A}$ & 269 (48.2) & $284(52.0)$ & & $0.91(0.70-1.19)$ \\
\hline & $\mathrm{G} / \mathrm{G}$ & $131(23.5)$ & 79 (14.5) & & $0.52(0.37-0.74)$ \\
\hline & $A$ & 0.52 & 0.6 & 0.0008 & $1.33(1.13-1.58)$ \\
\hline
\end{tabular}

Table 2. The impact of alcohol abuse on the development of AP in the presence of alcohol-induced pancreatitis in the carriers of the studied polymorphisms

\begin{tabular}{|c|c|c|c|c|c|c|}
\hline \multirow{2}{*}{ Genotype } & \multicolumn{3}{|c|}{ No risk factor $(f-)$} & \multicolumn{3}{|c|}{ Risk factor $\left(f_{+}\right)^{3}$} \\
\hline & Healthy individuals & Patients & OR $(95 \% \mathrm{Cl})_{\text {inter }} P 1$ & Healthy individuals & Patients & OR $(95 \% \mathrm{Cl})_{\text {inter }} P 1$ \\
\hline \multicolumn{7}{|c|}{ CYP2E1 (rs3813867) } \\
\hline $\mathrm{G} / \mathrm{G}$ & $119(90.8)$ & $173(96.6)$ & \multirow{2}{*}{$\begin{array}{c}0.34 \\
(0.13-0.94) \\
0.03\end{array}$} & $98(96.1)$ & $116(95.1)$ & \multirow{2}{*}{$\begin{array}{c}1.27 \\
(0.35-4.62) \\
0.72^{D}\end{array}$} \\
\hline $\mathrm{G} / \mathrm{C}-\mathrm{C} / \mathrm{C}$ & $12(9.2)$ & $6(3.4)$ & & $4(3.9)$ & $6(4.9)$ & \\
\hline
\end{tabular}

Note: ${ }_{\text {inte }} p$ - significance threshold in the analysis of interactions between SNPs and the risk factor; the risk factor $\left(f_{+}\right)^{3}$ is long-term alcohol abuse (over 10 years). 
Table 3. The analysis of the associations between the risk of infected pancreatic necrosis and the genotypes of the studied polymorphisms (the most significant models)

\begin{tabular}{|c|c|c|c|c|c|}
\hline \multirow[b]{2}{*}{ Gene (SNP ID) } & \multirow[b]{2}{*}{ Genotype, allele } & \multicolumn{2}{|c|}{$n(\%)$} & \multirow[b]{2}{*}{$p^{1}$} & \multirow[b]{2}{*}{ cor $\mathrm{OR}(95 \% \mathrm{Cl})^{2}$} \\
\hline & & $\begin{array}{l}\text { Control } \\
(n=573)\end{array}$ & $\begin{array}{l}\text { Patients with IPN } \\
\quad(n=97)\end{array}$ & & \\
\hline \multirow{2}{*}{$\begin{array}{l}\text { CYP1A1-462 T>C } \\
\text { rs1048943 }\end{array}$} & $\mathrm{T} / \mathrm{T}-\mathrm{T} / \mathrm{C}$ & 556 (99.8\%) & 93 (96.9\%) & \multirow{2}{*}{$0.0095^{\mathrm{R}}$} & 1.00 \\
\hline & $\mathrm{C} / \mathrm{C}$ & $1(0.2 \%)$ & $3(3.1 \%)$ & & $15.65(1.61-152.54)$ \\
\hline \multirow{2}{*}{$\begin{array}{l}\begin{array}{l}\text { ABCB1 }-3435 \mathrm{G}>\mathrm{A} \\
\mathrm{rs} 1045642\end{array}\end{array}$} & $\mathrm{~A} / \mathrm{A}-\mathrm{G} / \mathrm{A}$ & $427(76.5 \%)$ & $82(85.4 \%)$ & \multirow{2}{*}{$0.036^{\mathrm{R}}$} & 1.00 \\
\hline & $G / G$ & $131(23.5 \%)$ & $14(14.6 \%)$ & & $0.54(0.30-0.99)$ \\
\hline
\end{tabular}

Table 4. The analysis of the associations between the risk of pancreatic pseudocysts in patients with AP and the genotypes of the studied polymorphisms (the most significant model)

\begin{tabular}{|c|c|c|c|c|c|}
\hline \multirow{2}{*}{$\begin{array}{c}\text { Gene } \\
\text { (SNP ID) }\end{array}$} & \multirow[b]{2}{*}{ Genotype, allele } & \multicolumn{2}{|c|}{$n(\%)$} & \multirow[b]{2}{*}{$p^{1}$} & \multirow[b]{2}{*}{ cor $\mathrm{OR}(95 \% \mathrm{Cl})$} \\
\hline & & $\begin{array}{l}\text { Control } \\
(n=573)\end{array}$ & $\begin{array}{c}\text { Patients with PC } \\
\quad(n=101)\end{array}$ & & \\
\hline \multirow{2}{*}{$\begin{array}{l}\text { CYP1A1 -462 T>C } \\
\text { rs1048943 }\end{array}$} & $T / T-T / C$ & 556 (99.8\%) & $97(96 \%)$ & \multirow{2}{*}{$0.003^{\mathrm{D}}$} & 1.00 \\
\hline & $\mathrm{C} / \mathrm{C}$ & $1(0.2 \%)$ & $4(4 \%)$ & & $18.36(2.03-166.52)$ \\
\hline \multirow{2}{*}{$\begin{array}{l}\text { CYP2E1 -1293 G>C } \\
\text { rs3813867 }\end{array}$} & $\mathrm{G} / \mathrm{G}-\mathrm{C} / \mathrm{C}$ & 538 (96.1\%) & 92 (91.1\%) & \multirow{2}{*}{$0.05^{\circ D}$} & 1.00 \\
\hline & $\mathrm{G} / \mathrm{C}$ & 22 (3.9\%) & $9(8.9 \%)$ & & $2.43(1.07-5.56)$ \\
\hline \multirow{2}{*}{$\begin{array}{l}\begin{array}{l}\text { ABCB1 }-3435 \mathrm{G}>\mathrm{A} \\
\text { rs1045642 }\end{array}\end{array}$} & $\mathrm{A} / \mathrm{A}-\mathrm{G} / \mathrm{A}$ & 427 (76.5\%) & $86(85.2 \%)$ & \multirow{2}{*}{$0.04^{\mathrm{R}}$} & 1.00 \\
\hline & $G / G$ & $131(23.5 \%)$ & $15(14.8 \%)$ & & $0.55(0.30-0.99)$ \\
\hline
\end{tabular}

Table 5. The analysis of the associations between the risk of peripancreatic necrosis and the genotypes of the studied polymorphisms (the most significant model)

\begin{tabular}{|c|c|c|c|c|c|}
\hline \multirow{2}{*}{$\begin{array}{c}\text { Gene } \\
\text { (SNP ID) }\end{array}$} & \multirow[b]{2}{*}{ Genotype, allele } & \multicolumn{2}{|c|}{$n(\%)$} & \multirow[b]{2}{*}{$p^{1}$} & \multirow[b]{2}{*}{ cor $\mathrm{OR}(95 \% \mathrm{Cl})$} \\
\hline & & $\begin{array}{l}\text { Control } \\
(n=573)\end{array}$ & $\begin{array}{l}\text { Patients with PN } \\
\quad(n=111)\end{array}$ & & \\
\hline \multirow{2}{*}{$\begin{array}{l}\text { CYP1A1-462 T>C } \\
\text { rs1048943 }\end{array}$} & $\mathrm{T} / \mathrm{T}-\mathrm{T} / \mathrm{C}$ & $556(99.8 \%)$ & $106(96.4 \%)$ & \multirow{2}{*}{$0.003^{R}$} & 1.00 \\
\hline & $\mathrm{C} / \mathrm{C}$ & $1(0.2 \%)$ & $4(3.6 \%)$ & & $18.00(1.99-163.22)$ \\
\hline \multirow{2}{*}{$\begin{array}{l}A B C B 1-3435 \mathrm{G}>A \\
(\mathrm{rs} 1045642)\end{array}$} & $\mathrm{A} / \mathrm{A}-\mathrm{G} / \mathrm{A}$ & $427(76.5 \%)$ & $94(85.5 \%)$ & \multirow{2}{*}{$0.03^{R}$} & 1.00 \\
\hline & $\mathrm{G} / \mathrm{G}$ & $131(23.5 \%)$ & $16(14.6 \%)$ & & $0.56(0.31-0.98)$ \\
\hline
\end{tabular}

[24]. Research into the contribution of the ABCB1 rs1045642 polymorphism to the development of arterial hypertension and the evaluation of amlodipine-based therapy outcomes in different populations [25-27] have demonstrated a high antihypertensive effect in $\mathrm{TT}$ carriers; the researchers explained this effect by a decline in $A B C B 1$ expression. The same research team reported a link between the $\Pi$ genotype and the high risk of hemorrhagic complications in patients undergoing dabigatran therapy after knee replacement surgery. Our findings demonstrate that reduced $A B C B 1$ expression negatively affects the ability of the body to detoxify alcohol and increases the risk of AP in the carriers of the A allele.

On the whole, a milder course of AP was typical for the carriers of the $\mathrm{G} / \mathrm{G} A B C B 1 \mathrm{G}>\mathrm{A}$ (rs1045642) genotype; a more severe course was characteristic of the carriers of the $\mathrm{C} / \mathrm{C}$ CYP1A1 T>C (rs1048943) genotype.

\section{References}

1. Setiawan VW, Pandol SJ, Porcel J, Wilkens LR, Le Marchand L, Pike MC, et al. Prospective Study of Alcohol Drinking, Smoking, and Pancreatitis: The Multiethnic Cohort. Pancreas. 2016; 45 (6): 819-25.

2. Ali UA, Issa $Y$, Hagenaars JC, Bakker OJ, van Goor H, Nieuwenhuijs VB, Schaapherder AF. Risk of recurrent pancreatitis and progression to chronic pancreatitis after a first episode of acute pancreatitis. Clinical gastroenterology and hepatology. 2016; 14 (5): 738-46.

3. Mrozikiewicz-Rakowska B, Malinowski M, Nehring P, BartkowiakWieczorek J, Bogacz A, Żurawińska-Grzelka E, et al. The MDR1/

\section{CONCLUSIONS}

This study aimed at assessing the contribution of SNPs of some xenobiotic biotransformation genes to the development of $\mathrm{AP}$ in the residents of Kursk region has detected a few associations between the studied genotypes and the risk for AP /its complications, as well as established the trigger effect of the risk factors on the disease in the carriers of certain genotypes. Based on the analysis of genetic factors, including polymorphic variants of the genes coding for xenobiotic biotransformation enzymes, one can predict the risk of AP and the severity of its clinical course. This opens new opportunities for early diagnosis and timely prevention of the disease. Research into genetic polymorphisms might help to predict the outcomes of the disease and develop personalized approaches to its treatment and prevention. 
7. Wang $\mathrm{X}$, Cheung $\mathrm{CM}$, Lee WY, Or PM, Yeung JH. Major tanshinones of Danshen (Salvia miltiorrhiza) exhibit different modes of inhibition on human CYP1A2, CYP2C9, CYP2E1 and CYP3A4 activities in vitro. Phytomedicine. 2010; 17 (11): 868-75.

8. Kim MS, Lee DH, Kang HS, Park HS, Jung S, Lee JW, et al. Genetic polymorphisms of alcohol-metabolizing enzymes and cytokines in patients with alcohol induced pancreatitis and alcoholic liver cirrhosis. Korean J Gastroenterol. 2004; (43): 355-63.

9. Frenzer A, Butler WJ, Norton ID, Wilson JS, Apte MV, Pirola RC, et al. Polymorphism in alcohol-metabolizing enzymes, glutathione S-transferases and apolipoprotein E and susceptibility to alcoholinduced cirrhosis and chronic pancreatitis. J Gastroenterol Hepatol. 2002; (17): 177-82.

10. Yang B, O'Reilly DA, Demaine AG, Kingsnorth AN. Study of polymorphisms in the CYP2E1 gene in patients with alcoholic pancreatitis. Alcohol. 2001; (23): 91-7.

11. Burim RV, Canalle R, Martinelli Ade L, Takahashi C. Polymorphisms in glutathione S-transferases GSTM1, GSTT1 and GSTP1 and cytochromes P450 CYP2E1 and CYP1A1 and susceptibility to cirrhosis or pancreatitis in alcoholics. Mutagenesis. 2004; (19): 291-8.

12. Natalskij AA, Bogomolov AYu, Andrianova KV. Polimorfizm genov u bol'nyh hronicheskim pankreatitom. $V$ sbornike: Teorija i praktika sovremennoj hirurgii: Materialy $\mathrm{X}$ Vserossijskoj konferencii obshhih hirurgov; Rjazan', 2018; s. 219-220. Russian.

13. Smithies AM, Sargen $K$, Demaine AG, Kingsnorth AN. Investigations of the interleukin 1 gene cluster and its association with acute pancreatitis. Pancreas. 2000; 20 (3): 234-40.

14. Teich N, Bauer N, Mössner J, Keim V. Mutational screening of patients with nonalcoholic chronic pancreatitis: identification of further trypsinogen variants. The American journal of gastroenterology. 2002; 97 (2): 341-6.

15. Ulrich AB, Standop J, Schmied BM, Schneider MB, Lawson TA, Pour PM. Species differences in the distribution of drugmetabolizing enzymes in the pancreas. Toxicologic pathology. 2002; 30 (2): 247-53.

16. Dellinger EP, Forsmark CE, Layer P, Levy P, Maravi-Poma E, Petrov MS, et al. Determinant-based classification of acute pancreatitis severity: an international multidisciplinary consultation. Ann Surg. 2012; 256 (6): 875-80.

17. Banks PA, Bollen TL, Dervenis C, Gooszen HG, Johnson CD,

\section{Литература}

1. Setiawan VW, Pandol SJ, Porcel J, Wilkens LR, Le Marchand L, Pike MC, et al. Prospective Study of Alcohol Drinking, Smoking, and Pancreatitis: The Multiethnic Cohort. Pancreas. 2016; 45 (6): 819-25.

2. Ali UA, Issa $Y$, Hagenaars JC, Bakker OJ, van Goor $H$, Nieuwenhuijs VB, Schaapherder AF. Risk of recurrent pancreatitis and progression to chronic pancreatitis after a first episode of acute pancreatitis. Clinical gastroenterology and hepatology. 2016; 14 (5): 738-46.

3. Mrozikiewicz-Rakowska B, Malinowski M, Nehring P, BartkowiakWieczorek J, Bogacz A, Żurawińska-Grzelka E, et al. The MDR1/ ABCB1 gene rs 1045642 polymorphism in colorectal cancer. Archives of Medical Science. 2017; 13 (1).

4. Zhao L, Li K, Li W, Yang Z. Association between the C3435T polymorphism of ABCB1/MDR1 gene (rs1045642) and colorectal cancer susceptibility. Tumor Biology. 2013; 34 (3): 1949-57.

5. ВинникЮ. С., Черданцев Д. В., Маркова Е. В., Коноваленко А. Н., Первова О. В., Миллер М. С. Генетические аспекты панкреатита. Сибирский медицинский журнал (Иркутск). 2004; 43 (2).

6. Hosagrahara VP, Rettie AE, Hassett C, Omiecinski CJ. Functional analysis of human microsomal epoxide hydrolase genetic variants. Chem Biol Interact. 2004; (150): 149-59.

7. Wang $\mathrm{X}$, Cheung CM, Lee WY, Or PM, Yeung JH. Major tanshinones of Danshen (Salvia miltiorrhiza) exhibit different modes of inhibition on human CYP1A2, CYP2C9, CYP2E1 and CYP3A4 activities in vitro. Phytomedicine. 2010; 17 (11): 868-75.

8. Kim MS, Lee DH, Kang HS, Park HS, Jung S, Lee JW, et al. Genetic polymorphisms of alcohol-metabolizing enzymes and
Sarr MG, et al. Acute Pancreatitis Classification Working Group. Classification of acute pancreatitis 2012: revision of the Atlanta classification and definitions by international consensus. Gut. 2013; 62 (1): 102-11.

18. Klyaritskaya IL, Rabotyagova YuS. Novye faktory riska razvitija hronicheskogo pankreatita. Krymskij terapevticheskij zhurnal. 2012; (2): 63-69. Russian.

19. Lazarenko VA, Antonov AE. Sovremennoe sostojanie problemy vrednyh privychek kak faktora riska razvitija pankreatita. Social'nye aspekty zdorov'ja naselenija. 2017; 55 (3). Russian.

20. Furtwængler NA, de Visser RO. Lack of international consensus in low-risk drinking guidelines. Drug and alcohol review. 2013; 32 (1): 11-18.

21. Baranov VS, Baranova EV, Ivashhenko TYe, Aseev MV. Genom cheloveka i geny «predraspolozhennosti»: vvedenie v prediktivnuju medicinu. SPb.: Intermedika, 2000; 271 s. Russian.

22. Spicyn VA, Makarov SV, Paj GV, Bychkovskaja LS. Polimorfizm $\checkmark$ genah cheloveka, associirujushhihsja $s$ biotransformaciej ksenobiotikov. Vestnik VOGiS. 2006; 10 (1): 97-105. Russian.

23. Hubacek JA, Zakharov S. Response to 'CYP2E1 Polymorphism and Better Outcome After Methanol Poisoning'. Basic and clinical pharmacology and toxicology. 2015; 117 (1): 3-4.

24. Marzolini C, Paus E, Buclin T, Kim RB. Polymorphisms in human MDR1 (P-glycoprotein): recent advances and clinical relevance. Clinical Pharmacology and Therapeutics. 2004; 75 (1): 13-33.

25. Guo HQ, Zhang GN, Wang YJ, Zhang YK, Sodani K, Talele T, Chen ZS. $\beta$-Elemene, a compound derived from Rhizoma zedoariae, reverses multidrug resistance mediated by the ABCB1 transporter. Oncology reports. 2014; 31 (2): 858-66.

26. Sychev DA, Levanov AN, Shelekhova TV, Bochkov PO, Denisenko NP Ryzhikova KA, Kozlov AV. The impact of ABCB1 (rs1045642 and rs4148738) and CES1 (rs2244613) gene polymorphisms on dabigatran equilibrium peak concentration in patients after total knee arthroplasty. Pharmacogenomics and Personalized Medicine. 2018; (11): 127.

27. Sychev D, Shikh N, Morozova T, Grishina E, Ryzhikova K, Malova E. Effects of ABCB1 rs1045642 polymorphisms on the efficacy and safety of amlodipine therapy in Caucasian patients with stage I-II hypertension. Pharmacogenomics and personalized medicine. 2018; (11): 157

cytokines in patients with alcohol induced pancreatitis and alcoholic liver cirrhosis. Korean J Gastroenterol. 2004; (43): 355-63. 9. Frenzer A, Butler WJ, Norton ID, Wilson JS, Apte MV, Pirola RC, et al. Polymorphism in alcohol-metabolizing enzymes, glutathione S-transferases and apolipoprotein E and susceptibility to alcoholinduced cirrhosis and chronic pancreatitis. J Gastroenterol Hepatol. 2002; (17): 177-82.

10. Yang B, O'Reilly DA, Demaine AG, Kingsnorth AN. Study of polymorphisms in the CYP2E1 gene in patients with alcoholic pancreatitis. Alcohol. 2001; (23): 91-7.

11. Burim RV, Canalle R, Martinelli Ade L, Takahashi C. Polymorphisms in glutathione S-transferases GSTM1, GST11 and GSTP1 and cytochromes P450 CYP2E1 and CYP1A1 and susceptibility to cirrhosis or pancreatitis in alcoholics. Mutagenesis. 2004; (19): 291-8.

12. Натальский А. А., Богомолов А. Ю., Андрианова К. В. Полиморфизм генов у больных хроническим панкреатитом. В сборнике: Теория и практика современной хирургии: Материалы X Всероссийской конференции общих хирургов; Рязань, 2018; с. 219-220.

13. Smithies AM, Sargen K, Demaine AG, Kingsnorth AN. Investigations of the interleukin 1 gene cluster and its association with acute pancreatitis. Pancreas. 2000; 20 (3): 234-40.

14. Teich N, Bauer N, Mössner J, Keim V. Mutational screening of patients with nonalcoholic chronic pancreatitis: identification of further trypsinogen variants. The American journal of gastroenterology. 2002; 97 (2): 341-6.

15. Ulrich AB, Standop J, Schmied BM, Schneider MB, Lawson TA, Pour PM. Species differences in the distribution of drugmetabolizing enzymes in the pancreas. Toxicologic pathology. 
2002; 30 (2): 247-53.

16. Dellinger EP, Forsmark CE, Layer P, Levy P, Maravi-Poma E, Petrov MS, et al. Determinant-based classification of acute pancreatitis severity: an international multidisciplinary consultation. Ann Surg. 2012; 256 (6): 875-80.

17. Banks PA, Bollen TL, Dervenis C, Gooszen HG, Johnson CD, Sarr MG, et al. Acute Pancreatitis Classification Working Group. Classification of acute pancreatitis 2012: revision of the Atlanta classification and definitions by international consensus. Gut. 2013; 62 (1): 102-11.

18. Кляритская И. Л., Работягова Ю. С. Новые факторы риска развития хронического панкреатита. Крымский терапевтический журнал. 2012; (2): 63-69.

19. Лазаренко В. А., Антонов А. Е. Современное состояние проблемы вредных привычек как фактора риска развития панкреатита. Социальные аспекты здоровья населения 2017; 55 (3)

20. Furtwængler NA, de Visser RO. Lack of international consensus in low-risk drinking guidelines. Drug and alcohol review. 2013; 32 (1): 11-18.

21. Баранов В. С., Баранова Е. В., Иващенко Т. Э., Асеев М. В. Геном человека и гены «предрасположенности»: введение в предиктивную медицину. СПб.: Интермедика, 2000; 271 с.

22. Спицын В. А., Макаров С. В., Пай Г. В., Бычковская Л. С.
Полиморфизм в генах человека, ассоциирующихся с биотрансформацией ксенобиотиков. Вестник ВОГиС. 2006; 10 (1): 97-105.

23. Hubacek JA, Zakharov S. Response to 'CYP2E1 Polymorphism and Better Outcome After Methanol Poisoning'. Basic and clinical pharmacology and toxicology. 2015; 117 (1): 3-4.

24. Marzolini C, Paus E, Buclin T, Kim RB. Polymorphisms in human MDR1 (P-glycoprotein): recent advances and clinical relevance. Clinical Pharmacology and Therapeutics. 2004; 75 (1): 13-33.

25. Guo HQ, Zhang GN, Wang YJ, Zhang YK, Sodani K, Talele T, Chen ZS. $\beta$-Elemene, a compound derived from Rhizoma zedoariae, reverses multidrug resistance mediated by the ABCB1 transporter. Oncology reports. 2014; 31 (2): 858-66.

26. Sychev DA, Levanov AN, Shelekhova TV, Bochkov PO, Denisenko NP, Ryzhikova KA, Kozlov AV. The impact of ABCB1 (rs1045642 and rs4148738) and CES1 (rs2244613) gene polymorphisms on dabigatran equilibrium peak concentration in patients after total knee arthroplasty. Pharmacogenomics and Personalized Medicine. 2018; (11): 127.

27. Sychev D, Shikh N, Morozova T, Grishina E, Ryzhikova K, Malova E. Effects of ABCB1 rs1045642 polymorphisms on the efficacy and safety of amlodipine therapy in Caucasian patients with stage I-II hypertension. Pharmacogenomics and personalized medicine. 2018; (11): 157. 